\title{
FORMULATION AND EVALUATION OF LOTION AND CREAM OF NANOSIZED CHITOSAN-MANGOSTEEN (Garcinia mangostana L.) PERICARP EXTRACT
}

\author{
N. M. Saptarini ${ }^{1, *}$ and G. Hadisoebroto ${ }^{2}$ \\ ${ }^{1}$ Department of Pharmaceutical Analysis and Medicinal Chemistry, Faculty of Pharmacy, \\ Universitas Padjadjaran, Jatinangor-45363, (West Java) Indonesia \\ ${ }^{2}$ Department of Pharmacy, Faculty of Mathematics and Natural Sciences, Al Ghifari University, \\ Bandung-40293, (West Java) Indonesia \\ *E-mail: nyi.mekar@unpad.ac.id
}

\begin{abstract}
Nanosized chitosan-mangosteen pericarp extract has antiacne activity against Pseudomonas acnes. This study aimed to formulate and evaluate of lotions and creams of nanosized mangosteen pericarp extract. Lotions were formulated with various suspending agents, i.e. xanthan gum, carboxymethylcellulose, and bentonite magma. Creams were formulated with various ingredients of the oil phase, i.e. adeps lanae, liquid paraffin, and glycerin. Evaluation of lotions and creams for six-week observation includes organoleptic characteristics, homogeneity, $\mathrm{pH}$, viscosity, irritancy test, and a preference test. Data were shown as mean and standard deviation, then statistically analyzed using one-way analysis of variance. The results were showing that the mangosteen pericarp extract can be prepared as a nanosized particle, then formulated as lotions and creams with various formulas. All lotions and creams met the requirements and non-irritating. FC3 was the most preferred formula.
\end{abstract}

Keywords: Formulation Stability, Irritancy Test, Preference Test, Garcinia mangostana L., Nanosized Particle.

(c) RASĀYAN. All rights reserved

\section{INTRODUCTION}

Mangosteen (Garcinia mangostana L.) is in the Guttifarae family. The mangosteen pericarp contains biologically active compounds, such as xanthones, terpenes, anthocyanins, tannins, and phenols. ${ }^{1-3}$ Xanthones that have been identified include $\alpha$-mangostin, gartanin, and 8-desoxygartanin, ${ }^{4} \beta$ - and $\gamma$ mangostin, 1- and 3-isomangostin, mangostinone, mangostanol, mangostanin, garsinone B, garsinone D, garsinone E, 9-hydroxycalabaxanthone, and demethylcalabaxanthone. ${ }^{5}$ Xanthones have antioxidant, antitumor, antiinflammatory, antiallergy, antibacterial, antifungal, and antiviral activities. ${ }^{6-7}$ These xanthones may play a major role in therapeutic treatment of the diseases, but mechanisms of action are still unclear. ${ }^{8}$

$\alpha$-mangostin usually used as a mangosteen marker, due to the most abundant xanthones. $\alpha$-mangostin content from four mangosteen production center in West Java, Indonesia, were 12.39\% for Subang, 8.30\% for Purwakarta, 6.34\% for Bogor, and 5.70\% for Tasikmalaya when analysis with HPLC-UV detector. ${ }^{9}$ HPLC-PDA detect the $\alpha$-mangostin content at $8.56 \pm 0.003 \%$ in mangosteen pericarp extract from Tasikmalaya. ${ }^{10}$ The $\mathrm{IC}_{50}$ value of mangosteen extract from Ciamis was 13.73 ppm against 2,2diphenyl-1-picrylhydrazyl radicals. ${ }^{11}$ The advantages of nanotechnology in the pharmaceutical field are increasing the solubility and absorption, thereby dose reduction. Antiacne activity to Propionibacterium acnes of $1-2 \%$ nanosized chitosan-mangosteen pericarp extract is equivalent to products with antibiotics. $^{12}$ Nanosized mangosteen pericarp extract $(213,6 \mathrm{~nm})$ was shown the best antibacterial activity compared to crude extract with a particle size of 20 mesh and 40 mesh. $^{13}$

The purpose of this study was to make formulas and evaluate lotions and creams of nanosized chitosanmangosteen pericarp extract. Lotions and creams are chosen as topical antiacne preparations, due to easy to spread and clean. ${ }^{14}$ Lotions were formulated with three different suspending agents, i.e. xanthan gum,

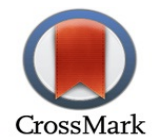


carboxymethylcellulose and bentonite magma. Creams were formulated with various ingredients of the oil phase, i.e. adeps lanae, liquid paraffin, and glycerin. The novelty of this study is lotion and cream formulation of nanosized chitosan-mangosteen pericarp extract which expected to improve the absorption of secondary metabolites in the extract. While the rationality was previous studies that showed antiacne activity of nanosized chitosan-mangosteen pericarp extract to $P$. acnes.

\section{EXPERIMENTAL}

\section{Materials}

Mangosteen pericarp was obtained from mangosteen plantations in Mekarmukti Village, Ciamis district, West Java, Indonesia. The deep purple mangosteen was harvested from the 5-year-old mangosteen tree. Mangosteen was identified by Plant Taxonomy Laboratory, Department of Biology, Universitas Padjadjaran with No. 215/HB/07/2018. Glycerin, xanthan gum, carboxymethylcellulose, bentonite magma, stearic acid, liquid paraffin, adeps lanae, triethanolamine, methylparaben, and propylparaben were cosmetic grade and purchased from TTK Science Co. (Thailand). Bismuth subnitrate, glacial acetic acid, potassium iodide, acetic anhydrate, sulfuric acid, ammonia, chloroform, ether, magnesium powder, amyl alcohol, vanillin sulfate, hydrochloric acid, potassium hydroxide, iron chloride, sodium hydroxide, gelatin, and ethanol were analytical grade and purchased from Merck (Germany).

\section{Extraction and Phytochemical Screening of Mangosteen Pericarp}

Mangosteen pericarp powder was macerated with $96 \%$ ethanol at a ratio 1:10 for 3 days. Every $24 \mathrm{~h}$, the solvent was replaced. Extracts were collected and concentrated using a rotary evaporator, then the yield was calculated. Phytochemical screening based on color reactions using modified Farnsworth method. ${ }^{15}$

\section{Production of Nanosized Chitosan-Mangosteen Pericarp Extract}

A total of $2 \mathrm{~g}$ of concentrated mangosteen pericarp extract was dissolved in $50 \mathrm{~mL}$ of $70 \%$ ethanol, then mixed with $2 \%$ chitosan solution and diluted with aqua dest to $1 \mathrm{~L}$. Gradually, this mixture was added to a mixture of $0.1 \%$ sodium tripolyphosphate (Na-TPP) solution with a ratio $1: 1$ with stirring at $12,500 \mathrm{rpm} .{ }^{12}$

\section{Formulation of Lotion and Cream}

The lotion was prepared with the composition as in Table-1. Each suspending agent (xanthan gum, carboxymethylcellulose, bentonite magma) was swelled with hot water, then the preservative solution was added, and mixed until homogenous. ${ }^{16}$ Nanosized chitosan-mangosteen pericarp extract was dissolved in glycerin and mixed with lotion base.

The cream was prepared with the composition as in Table-2. The emulsifier (stearic acid) and other oilsoluble components were heated to $70{ }^{\circ} \mathrm{C}$ (part A). The preservatives and other water-soluble components were dissolved in the aqueous phase (part B) and heated to $70^{\circ} \mathrm{C}$. The aqueous phase was added to the oil phase with continuous stirring. ${ }^{17}$ Nanosized chitosan-mangosteen pericarp extract was mixed to the cream base.

Table-1: Lotion Formula of Nanosized Chitosan-Mangosteen Pericarp Extract

\begin{tabular}{l|c|c|c}
\hline \multirow{2}{*}{ Ingredient } & \multicolumn{3}{c}{ Concentration (\%) b/v } \\
\cline { 2 - 4 } & FL1 & FL2 & FL3 \\
\hline Nanosized chitosan-mangosteen pericarp extract & 2 & 2 & 2 \\
\hline Glycerin & 20 & 20 & 20 \\
\hline Xanthan gum & 0.5 & - & - \\
\hline Carboxymethylcellulose & - & 2 & - \\
\hline Bentonite magma & - & - & 5 \\
\hline Methylparaben & 0.07 & 0.07 & 0.07 \\
\hline Propylparaben & 0.03 & 0.03 & 0.03 \\
\hline Aquadest & 77.4 & 75.9 & 72.9 \\
\hline
\end{tabular}

\section{Evaluation of Lotion and Cream}

All lotions and creams were evaluated using standard methods of general characterization and physical evaluation. Observations were carried out for 6 weeks and performed triplicate. Irritancy test and preference tests were conducted after being approved by the Health Research Ethics Committee of 
Government Hospital of Dr. Hasan Sadikin Bandung, West Java, Indonesia. These tests were performed on 20 human volunteers and conducted after taking their informed consent.

Table-2: Cream Formula of Nanosized Chitosan-Mangosteen Pericarp Extract

\begin{tabular}{l|c|c|c}
\hline \multirow{2}{*}{ Ingredient } & \multicolumn{3}{c}{ Concentration $(\%) \mathrm{b} / \mathrm{v}$} \\
\cline { 2 - 4 } & FC1 & FC2 & FC3 \\
\hline Nanosized chitosan-mangosteen pericarp extract & 2 & 2 & 2 \\
\hline Stearic acid & 14.5 & 14.2 & 20 \\
\hline Liquid paraffin & 25 & - & - \\
\hline Glycerin & - & 10 & - \\
\hline Adeps lanae & - & - & 2 \\
\hline Triethanolamine & 1.5 & 1 & 1 \\
\hline Methylparaben & 0.07 & 0.07 & 0.07 \\
\hline Propylparaben & 0.03 & 0.03 & 0.03 \\
\hline Aquadest & 56.9 & 72.7 & 74.9 \\
\hline
\end{tabular}

1. Organoleptic Characteristics: Organoleptic characteristics were assessed from color and scent. ${ }^{18}$

2. Homogeneity: Homogeneity was analyzed by visual inspection for the appearance and existence of any clog. ${ }^{18}$

3. Presence of Foreign Particles: A small amount of formulation was spread on a glass slide free from grease and was observed against the diffused light to check for the presence of foreign particles. ${ }^{19}$

4. pH Evaluation: The $\mathrm{pH}$ of $1 \%$ solution of lotions and creams was measured using a digital $\mathrm{pH}$ meter (Beckman, Germany). ${ }^{19}$

5. Viscosity: Viscosity was determined by Brookfield Viscometer II + model using spindle no S -64 at $20 \mathrm{rpm}$ at a temperature of $25^{\circ} \mathrm{C}$. The results were recorded after the viscotester shows a stable number. ${ }^{20}$

6. Spreadability: The formula was applied in between two glass slides, then pressed to obtain a uniform film thickness. Thereafter a weight $(10 \mathrm{~g})$ was added to the pan and the top plate was subjected to pull with the help of string attached to the hook. The time in which the upper glass slide moves over the lower plate to cover a distance of $10 \mathrm{~cm}$ is noted and calculate the spreadability (S) using the formula. ${ }^{20}$

$$
\text { Spreadability }=\frac{\text { Weight tied to the upper slide } x \text { Length of glass slide }}{\text { Time taken to separate the slides }}
$$

7. Irritancy Test: The lotions and creams were applied on the dorsal left-hand surface. Irritancy, erythema, edema was checked every hour up to $24 \mathrm{~h}$ and reported. ${ }^{21}$

8. Preference Test: The parameters of preference tests based on sensory evaluation were a scent, color, and sensation on the skin. The level of preference was assessed using a numerical scale, i.e. $5=$ like extremely, 4 = like, 3 = neutral, 2 = dislike, 1 = dislike extremely. ${ }^{22}$

\section{RESULTS AND DISCUSSION}

Maceration was conducted to obtain the chemical components in simplicia. Ethanol, with a polarity index of 5.2, ${ }^{23}$ was used as the solvents due to universal solvents, so that various polar and nonpolar compounds can be extracted from mangosteen pericarp. The yield of concentrated extract was $18.59 \%$ of dark purple with a characteristic scent of mangosteen. The yield of this study $(18.59 \%)$ was lower than Thailand mangosteen, i.e. $24.05 \%,{ }^{24}$ due to the difference in a growth location. Thailand is a better growth location than Indonesia. Phytochemical screening results were shown that simplicia and mangosteen extract contained anthocyanins, flavonoids, tannins, terpenoids, saponins, and alkaloids. The results of phytochemical screening show that all secondary metabolites in the simplicia can be attracted by ethanol solvents. These results were accorded to literature. ${ }^{25}$

The ionic gelation method was used to produce nanosized chitosan-mangosteen pericarp extract, with NaTPP as a crosslinking agent with chitosan. The extract will be coated or in the pores of the formed nanosized chitosan-mangosteen pericarp extract. Based on the particle size and encapsulation efficiency, the synthesis of nanosized chitosan-mangosteen pericarp extract was conducted in a ratio of 1:1, while the 
RASĀYAN J. Chem.

Vol. 13 | No. 2 |789 - 795| April - June | 2020

ratio of chitosan: Na-TPP was 10:7. The character of nanosized chitosan-mangosteen pericarp extract was 200-500 nm in size with yellow and the characteristic scent of mangosteen. This result was accorded with the literature. ${ }^{12}$ TPP cause higher Intra and inter cross-linkages to form larger particles. ${ }^{26}$

Thiolated chitosans are hydrophilic polymers with thiol groups on their side chains. ${ }^{27}$ Thiolated chitosan has unique properties, i.e. non-toxic and safe polymer, ${ }^{28}$ mucoadhesive properties to increase uptake properties ${ }^{29}$ display enzyme inhibitory properties, and can open intercellular tight junctions to facilitate transportation into the cell. ${ }^{27}$

The base of a topical preparation is important. Lotion and cream were selected to be formulated for nanosized chitosan-mangosteen pericarp extract. Lotions are thicker than solutions and creams are thicker than lotions. Lotions have a high moisture tendency, while creams have moderate moisture tendencies. ${ }^{30}$ This study was aimed to compare the effect of the formulation on the stability and the subject acceptance. The results of the evaluation of lotions and creams were:

\section{Organoleptic Characteristics}

The color and the scent of the lotions and creams were stable during the 6 weeks of observation. The stable scent was caused by the right container which tightly closed and right storage which protected from light. The color of nanosized chitosan-mangosteen pericarp extract was yellow, due to chitosan as adsorbents which absorb the dark purple of mangosteen extract. All cream was yellowish-white, due to cream bases were white which no alter the color of nanosized chitosan-mangosteen pericarp extract. The color of lotion FL1 was yellow, due to white or yellowish-white xanthan gum; while FL2 was orange, due to white or slightly yellowish carboxymethylcellulose; and FL3 was brown, due to brown bentonite magma.

\section{Homogeneity}

There was no clog in the lotions and creams during the 6 weeks of observation. These results showed that the bases of lotion and cream were homogeneous, due to prior grinding of the base materials.

\section{Presence of Foreign Particles}

There were no foreign particles in the lotions and creams during the 6 weeks of observation, due to a tightly closed container to store the preparations.

\section{pH Evaluation}

There was no significant $\mathrm{pH}$ alteration in lotions and creams $(P=0.999)$. The $\mathrm{pH}$ value of lotions was ranging from 4.7 to 6.0 and the creams were ranging from 6.4 to 7.0 (Fig.-1). The $\mathrm{pH}$ of normal skin varies, range from 4.0 to $7.0{ }^{31}$ The $\mathrm{pH}$ value in FL1 and FL2 was decreasing, due to hydrolysis of xanthan gum and carboxymethylcellulose which is carbohydrate derivatives. FL3 with bentonite magma which is a clay derivative can provide a stable $\mathrm{pH}$ value. The cream $\mathrm{pH}$ values were higher than lotions and closer to neutral $\mathrm{pH}$ because triethanolamine in creams can adjust and buffer the $\mathrm{pH} \cdot{ }^{32} \mathrm{FC} 2$ was the most stable compared to $\mathrm{FC} 1$ and $\mathrm{FC} 3$, because triethanolamine more dissolve glycerin than paraffin liquid and adeps lanae, ${ }^{30}$ so FC2 base was more stable than FC1 and FC3.

\section{Viscosity}

The stability and application behavior of lotions and creams are important factors for subject acceptance. The viscosity of creams and lotions are influenced by the ingredients and production process. The viscosity was measured to ensure the products feel and behave on the skin. ${ }^{33-34}$ The cream viscosity was ranging from 360 to $450 \mathrm{cps}$ (Fig.-2) was similar to another study by Tchienou et al., ${ }^{35}$ i.e. $290-480 \mathrm{cps}$. The lotion viscosity was lower than cream, ranging from 147.5 to $190 \mathrm{cps}$, due to higher water content. FC3 which contains adeps lanae was the thickest cream compared to FC2 which contains glycerin and FC1 which contain liquid paraffin. This result was proportional to the percentage and compound density in the creams, i.e. $1.26 \mathrm{~g} / \mathrm{cm}^{3}$ for glycerin, $0.85 \mathrm{~g} / \mathrm{cm}^{3}$ for liquid paraffin, and $0.93-0.95 \mathrm{~g} / \mathrm{cm}^{3}$ for adeps lanae. ${ }^{32} \mathrm{FC} 3$ was the most stable during storage because adeps lanae can maintain base stability. The viscosity reduction in the lotions occurs due to suspending agent hydrolysis. The viscosity values of 
RASĀYAN J. Chem.

Vol. 13 | No. 2 |789 - 795| April - June | 2020

creams were higher than lotions, due to higher liquid content in lotions, while creams contain oily compounds which make it more viscous.

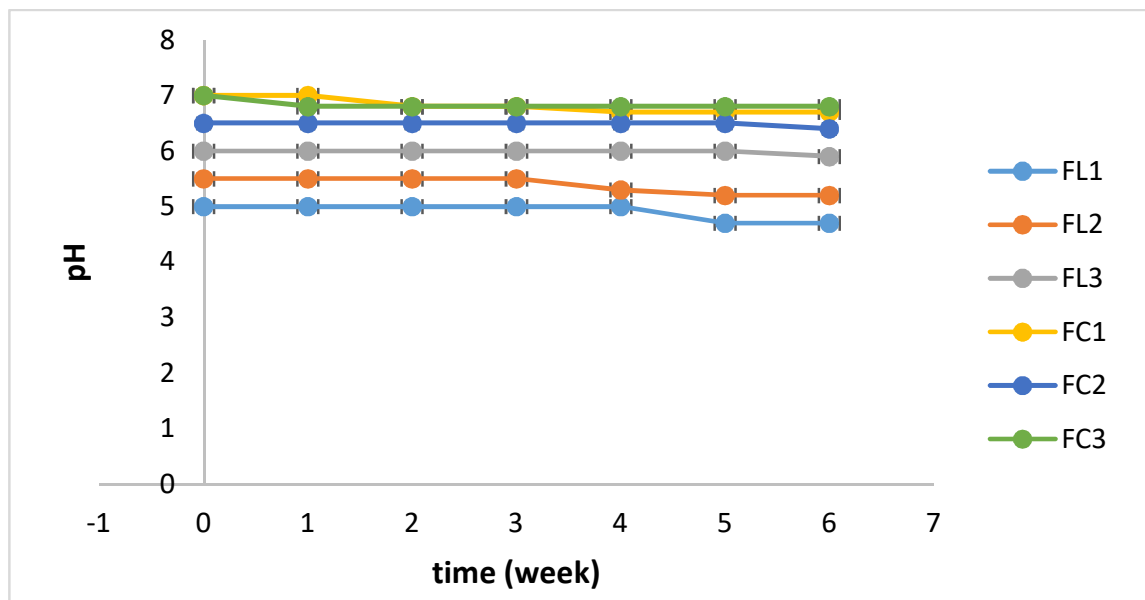

Fig.-1: The $\mathrm{pH}$ Values $(\mathrm{n}=3)$ of Lotion (FL) and Cream (FC) during the 6 Weeks of Observation

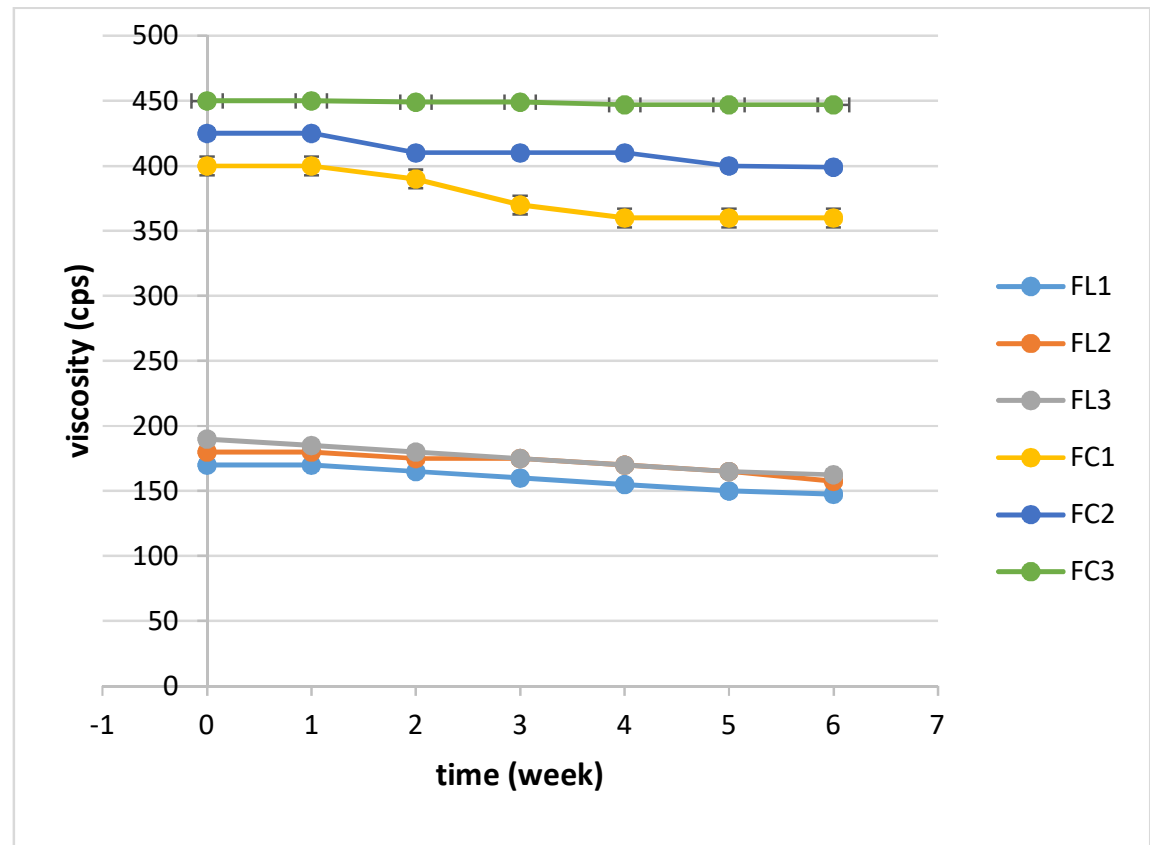

Fig.-2: Viscosity Value ( $\mathrm{n}=3$ ) of Lotion $(\mathrm{FL})$ and Cream $(\mathrm{FC})$ during the 6 Weeks of Observation

\section{Spreadability}

Creams and lotions were showed shear-thinning behavior so spread easily. The spreadability of lotions were ranging from $7.04 \pm 0.21$ to $8.17 \pm 0.16 \mathrm{~g} . \mathrm{cm} / \mathrm{s}$ while creams were ranging from $5.26 \pm 0.18$ to 6.24 $\pm 0.24 \mathrm{~g} . \mathrm{cm} / \mathrm{s}$. This value was similar to another study by Tchienou et al..$^{35}$ There was a correlation between spreadability values with viscosity values, the viscous formula has a smaller spreadability value.

\section{Irritancy Test}

All lotions and creams were safe and did not develop any skin irritation, lesion or inflammation. All tested formulations were well tolerated. This result showed that all ingredients and concentrations of all ingredients were safe. 


\section{Preference Test}

Preference test for preparations must be investigated through the sensory test, directly on the skin. ${ }^{36}$ The most preferred formulas were FL1 for color, FC3 for scent, and FC1 for sensations on the skin (Fig.-3). Creams were preferred over the lotions, due to fast permeate and dry. FC3 was the most preferred formula because all parameters give good results.

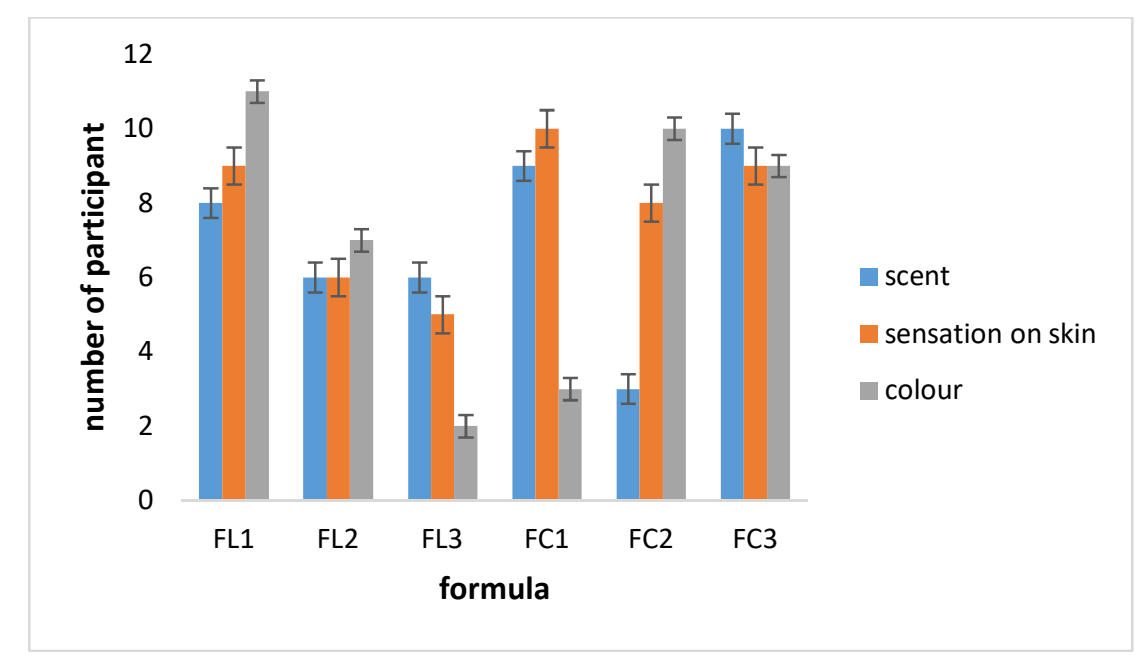

Fig.-3: The Graph of Preference Test $(n=3)$ on 20 of Participant

\section{CONCLUSION}

All lotions and creams met the requirements and non-irritating with FC3 was the most preferred formula.

\section{ACKNOWLEDGMENT}

The authors would like to thank Ayu Rahmawati, Dian Nurdiani, and Ardian Baitariza for technical assistance.

\section{REFERENCES}

1. W. Mahabusarakam, P. Wiriyachitra, S. Phongpaichit, Journal of the Science Society of Thailand, 12(4), 239(1986).

2. K. Balasubramanian, K. Rajagopalan, Phytochemistry, 27(5), 1552(1988), DOI:10.1016/00319422(88)80242-5

3. M.T. Chomnawang, S. Surassmo, V.S. Nukoolkarn, W. Gritsanapan, Journal of Ethnopharmacy, 101(1-3), 330(2005), DOI:10.1016/j.jep.2005.04.038

4. T. Govindachari, P. Kalyanaraman, N. Muthukumaraswamy, B.R. Pai, Tetrahedron, 27(16), 3919(1971), DOI: 10.1016/S0040-4020(01)98253-5

5. D. Obolskiy, I. Pischel, N. Siriwatanametanon, M. Heinrich, Phytotherapy Research, 23(8), 1047(2009), DOI:10.1002/ptr.2730

6. K.A. Steinmetz, J.D. Potter, Journal of the American Dietetic Association, 96(10), 1027(1996), DOI: 10.1016/S0002-8223(96)00273-8

7. J. Yang, R.H. Liu, L. Halim, LWT-Food Science Technology, 42(1),1(2009), DOI:10.1021/jf020665f

8. S. Jindarat, Journal of the Medical Association of Thailand, 97(2), S196(2017).

9. M. Muchtaridi, D. Suryani, W.A. Qosim, N.M. Saptarini, International Journal of Pharmacy and Pharmaceutical Sciences, 8(8), 232(2016).

10. M. Muchtaridi, M. Prasetio, N.M. Saptarini, F.A. Saputri, Rasayan Journal of Chemistry, 11(3), 973(2018), DOI:10.31788/RJC.2018.1132098.

11. N.M. Saptarini, G. Hadisoebroto, B. Kusuma, Proceeding of UNJANI Pharmacy National Seminar, 205(2015). 
RASĀYAN J. Chem.

Vol. 13 | No. 2 |789 - 795| April - June | 2020

12. E. Rismana, S. Kusumaningrum, O. Bunga, N. Nizar, M. Marhamah M, Media Litbangkes, 24(1), 19(2014).

13. P. Sugita, S. Arya, A. Ilmiawati, B. Arifin, Rasayan Journal of Chemistry, 10(3), 707(2017), DOI: $10.7324 /$ RJC.2017.1031766

14. L. Lachman, A. Herbert, J. Lieberman, L. Kanig, The theory and practice of industrial pharmacy, $3^{\text {rd }}$ ed, Lea And Febiger, US (1994).

15. N.R. Fransworth, Journal of Pharmaceutical Sciences, 1(5), 247(1966), DOI: $10.1002 /$ jps.2600550302

16. T. Mitsui, New Cosmetic and Science, Elsevier, Amsterdam (1997).

17. N.K. Jain, G.D. Gupta, Modern Dispensing Pharmacy, $2^{\text {nd }}$ ed, Pharma Med Press, Hyderabad, India (2009).

18. A. Nawaz, S.U. Jan, N.R. Khan, A. Hussain, G.M. Khan, Pakistan Journal of Pharmaceutical Sciences, 26, 617(2013), DOI:10.1590/0001-3765201620160162

19. H. Chaudhary, A. Rohilla, P. Rathee, V. Kumar, International Journal of Biological Macromolecules, 55, 246-53(2013), DOI:10.1016/j.ijbiomac.2013.01.015

20. S.D. Ashwini, S.K. Somishwar, S.S. Shweta, American Journal of Ethnomedicine, 1(5), 313(2014).

21. B. Gidwani, R.N. Alaspure, N.J. Duragkar, V. Singh, S.P. Rao, S.S. Shukla, Iranian Journal of Dermatology, 13, 122(2010).

22. M. Meilgaard, G.V. Civille, B.T. Carr, Sensory Evaluation Techniques, CRC Press Inc, Boca Raton, Florida(2007).

23. C.R. Snyder, J.J. Kirkland, J.L. Glajach, Practical HPLC Method development, $2^{\text {nd }}$ ed, John Wiley and Sons Inc, New York (1997).

24. S. Pan-on, S. Rujivipat, A. Ounaroon, C. Kongkaew, W. Tiyaboonchai, International Journal of Applied Pharmaceutics, 10(5), 202(2018), DOI:10.22159/ijap.2018v10i5.28247

25. L. Puspitasari, D.A. Swastini, C.I.A. Arisanti, Udayana Pharmaceutical Journal, 5, 1(2013).

26. N.K. Al-Nemrawi, S.S.M. Alsharif, R.H. Dave, International Journal of Applied Pharmacy, 10(5), 60(2018), DOI:10.22159/ijap.2018v10i5.26375

27. A. Bernkop-Schnurch, Advanced Drug Delivery Reviews, 57,1569(2005), DOI: 10.1016/j.addr.2005.07.002

28. D. Guggi, N. Langoth, M.H. Hoffer, M. Wirth, A. Bernkop-Schnurch, International Journal of Pharmaceutics, 278, 353(2004), DOI:10.1016/j.ijpharm.2004.03.016

29. A.E. Clausen, C.E. Kast, A. Bernkop-Schnurch, Pharmaceutical Research, 19, 602(2002), DOI: 10.1023/A:1015345827091

30. S.E. Wolverton, Comprehensive Dermatologic Drug Therapy, WB Saunders, Philadelphia (2001).

31. J.W. Fluhr, P.M. Elias, Exogenous Dermatology, 1, 163(2002), DOI:10.1159/000066140

32. The Merck Index Online. Available from: https://www.rsc.org/Merck-Index/ [Last accessed on January $2^{\text {nd }} 2019$ ]

33. M.L. Yao, J.C. Patel, Applied Rheology, 11, 83(2001), DOI:10.1515/arh-2001-0005

34. M-S. Kwak, H-J. Ahn, K-W. Song, Korea-Australia Rheology Journal, 27(3), 241(2001).

35. G.E.D. Tchienou, R.K.T. Tsague, T.F.M. Pega, V. Bama, A. Bamseck, S.D. Sokeng, M.B. Ngassoum, Cosmetics, 5(7), 1(2018), DOI:10.3390/cosmetics5010007

36. R. Brummer, S. Godersky. Colloids and Surfaces A: Physicochemical and Engineering Aspects, 152, 89(1999), DOI:10.1016/S0927-7757(98)00626-8

[RJC-5533/2019] 